\title{
Modelling bluetongue risk in Kazakhstan
}

\author{
Sarsenbay K. Abdrakhmanov ${ }^{1}$ B, Kanatzhan K. Beisembayev' ${ }^{1}$ Akmetzhan A. Sultanov², \\ Yersyn Y. Mukhanbetkaliyev ${ }^{1} \mathbb{B}$, Ablaikhan S. Kadyrov ${ }^{1} \mathbb{B}$, Altay Y. Ussenbayev ${ }^{\top} \mathbb{D}$, Aigerim Y. Zhakenova ${ }^{1}$ and \\ Paul R. Torgerson ${ }^{3 *}$ (1)
}

\begin{abstract}
Background: Bluetongue is a serious disease of ruminants caused by the bluetongue virus (BTV). BTV is transmitted by biting midges (Culicoides spp.). Serological evidence from livestock and the presence of at least one competent vector species of Culicoides suggests that transmission of BTV is possible and may have occurred in Kazakhstan.

Methods: We estimated the risk of transmission using a mathematical model of the reproduction number $R_{0}$ for bluetongue. This model depends on livestock density and climatic factors which affect vector density. Data on climate and livestock numbers from the 2466 local communities were used. This, together with previously published model parameters, was used to estimate $R_{0}$ for each month of the year. We plotted the results on isopleth maps of Kazakhstan using interpolation to smooth the irregular data. We also mapped the estimated proportion of the population requiring vaccination to prevent outbreaks of bluetongue.
\end{abstract}

Results: The results suggest that transmission of bluetongue in Kazakhstan is not possible in the winter from October to March. Assuming there are vector-competent species of Culicoides endemic in Kazakhstan, then low levels of risk first appear in the south of Kazakhstan in April before spreading north and intensifying, reaching maximum levels in northern Kazakhstan in July. The risk declined in September and had disappeared by October.

Conclusion: These results should aid in surveillance efforts for the detection and control of bluetongue in Kazakhstan by indicating where and when outbreaks of bluetongue are most likely to occur. The results also indicate where vaccination efforts should be focussed to prevent outbreaks of disease.

Keywords: Bluetongue, Culicoides, Epidemiology, Transmission Kazakhstan, Livestock, Sheep, Cattle, Risk, Basic reproduction number, Geographical information systems, Mathematical modelling

\section{Background}

Bluetongue (BT) is a viral disease of ruminants caused by bluetongue virus (BTV), which has now been identified on all continents except Antarctica [1-5]. Hematophagous midges in the genus Culicoides are biological vectors that transmit BTV from infected to susceptible ruminants; thus the global distribution of BTV coincides with the distribution of competent Culicoides insect vectors and appropriate climatic conditions. The extrinsic

\footnotetext{
*Correspondence: paul.torgerson@uzh.ch

${ }^{3}$ Section of Epidemiology, Vetsuisse Faculty, University of Zürich, Zürich, Switzerland

Full list of author information is available at the end of the article
}

incubation period for the virus in the insect vector is many weeks at the minimum temperature for replication of the virus which is $11-13{ }^{\circ} \mathrm{C}$. At higher temperatures, this is reduced to about 5 days at $25^{\circ} \mathrm{C}$ and 2.5 days at $35{ }^{\circ} \mathrm{C}$ [6]. Specifically, BTV exists in an extensive band that includes tropical, subtropical, and temperate regions of the world between latitudes of approximately $40^{\circ}$ north and $35^{\circ}$ south [5]. Exceptions include regions of Asia and western North America, where BTV infection of cattle and sheep occurs as far as $50^{\circ}$ north $[7,8]$ and, most recently, northern Europe. Serologically positive animals have been previously reported in Kazakhstan [9] and in Xinjiang in neighbouring China [4]. Cattle imported from Russia into Kazakhstan have also been reported as

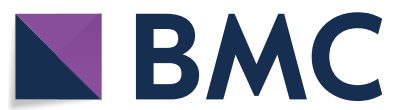

(c) The Author(s) 2021. Open Access This article is licensed under a Creative Commons Attribution 4.0 International License, which permits use, sharing, adaptation, distribution and reproduction in any medium or format, as long as you give appropriate credit to the original author(s) and the source, provide a link to the Creative Commons licence, and indicate if changes were made. The images or other third party material in this article are included in the article's Creative Commons licence, unless indicated otherwise in a credit line to the material. If material is not included in the article's Creative Commons licence and your intended use is not permitted by statutory regulation or exceeds the permitted use, you will need to obtain permission directly from the copyright holder. To view a copy of this licence, visit http://creativecommons.org/licenses/by/4.0/. The Creative Commons Public Domain Dedication waiver (http://creativeco mmons.org/publicdomain/zero/1.0/) applies to the data made available in this article, unless otherwise stated in a credit line to the data. 
seropositive [10]. Cattle are usually asymptomatic carriers after being infected with BTV, but can be a potential virus reservoir and source of infection on the farm [4]. The present distribution and risk of bluetongue in Kazakhstan is unknown. The extent of suitable vectors of the virus is also unknown, although the vector-competent species Culicoides obsoletus has been found in eastern Kazakhstan [11, 12]. Adult Culicoides are killed by cold winter temperatures, and BTV infections typically do not last for more than 63 days [13], which is not long enough for BT-infected animals to remain infectious to the vectors for the duration of the winter. However, in inner Mongolia, which also has cold winters, BT appears to be endemic [14], indicating that the virus can continue to transmit following long periods when the vector in inactive. Therefore, it seems that the virus somehow survives in overwintering midges or animals. A number of mechanisms have been speculated. These include levels of vector activity during mild winters, low numbers of chronic or latent infections in cattle, and horizontal or vertical transmission between cattle. Less likely mechanisms include alternative but unknown reservoir hosts or alternative vectors that are better able to overwinter [15].

The risk of transmission is believed to be affected by the ruminant density, summer temperature, and rainfall (see reproduction number in the "Methods" section). Density of livestock affects the transmission between animals and the Culicoides vector, whilst higher temperatures and rainfall are required for vector activity. For example, $C$. obsoletus/C. scoticus occurs in regions where annual rainfall is greater than $700 \mathrm{~mm}$, and adult activity starts when the temperature rises above $10{ }^{\circ} \mathrm{C}$ [16]. Thus, an important part of developing a risk map for Kazakhstan is to model climate data with livestock density to estimate risk of transmission. Therefore, the objective of this study was to combine this data with a model for the basic reproduction model to indicate the geographical and seasonal risk of transmission in Kazakhstan.

\section{Methods}

\section{Basic reproductive number of bluetongue}

The basic reproduction number, $R_{0}$, is defined as the expected number of secondary cases caused by one infectious individual introduced into a naïve population. $R_{0}$ is a measure of the success of invasion into a population; if the value of $R_{0}$ is higher than 1 , an outbreak of the infectious agent is possible, whereas if $R_{0}$ is less than 1 , the infection is likely to die out [17]. Maps indicating the value of $R_{0}$ can be used to identify areas with a higher probability of a major outbreak after an introduction.
This concept has been used to develop risk maps for directly transmitted diseases such as foot-and-mouth disease [18]. Therefore, to model the areas of risk for BT in Kazakhstan, established models for $R_{0}$ were used.

The basic reproduction number of BT has been defined by [19] as:

$R_{0}=\sqrt{\frac{a^{2} b c q v h_{c}}{\gamma_{c}\left(h_{c}+h_{s}\right)^{2} \mu(q+\mu)}+\frac{a^{2} b c q v h_{s}}{\gamma_{c}\left(h_{c}+h_{s}\right)^{2} \mu(q+\mu)}}$

This is where $c=$ the transmission probability following a bite by an infected Culicoides, $\gamma_{\mathrm{c}}$ and $\gamma_{\mathrm{s}}$ are the rate of loss of infectiousness in cattle and sheep, respectively ( $1 / \gamma$ is the duration of infectiousness), $v$ the local density of Culicoides, $a$ is the biting rate (which equals the reciprocal of the length of the gonotrophic cycle), $h_{\mathrm{s}}$ and $h_{\mathrm{c}}$ are the population densities of sheep and cattle, respectively, $c$ is the transmission probability from cattle or sheep to Culicoides following a bite, $b$ is the transmission efficiency from Culicoides to host, $q$ is the rate at which the Culicoides becomes infectious, and $\mu$ is the Culicoides mortality rate. Furthermore, $a, q$, and $\mu$ are temperature-dependent, and $v$ is dependent on climatic conditions. The values for the various parameters are given in Table 1. A pictorial representation is illustrated in Fig. 1.

\section{Data}

Kazakhstan is divided into 14 first administrative level regions (or oblasts), and these are subdivided into 170 second administrative level districts (or rayons). The rayons are further subdivided into 2466 third administrative level village districts (or selski okrugs, SO). Data for the

Table 1 Parameter values for the basic reproductive ratio

\begin{tabular}{ll}
\hline Parameter & Value \\
\hline$b$ & 1 \\
$c$ & 0.05 \\
$\gamma_{c}$ & 0.04 \\
$\gamma_{s}$ & 0.125 \\
$v / 100$ & $\log _{\mathrm{e}}(v+1) \sim-0.856+0.076 \mathrm{~T}_{\mathrm{i}, \mathrm{i}}+0.048 \mathrm{~T}_{\mathrm{i}-}$ \\
& $37, \mathrm{i}+2.913 \mathrm{P}_{\mathrm{i}-100 \mathrm{j}-16}$ \\
$a$ & $a \sim 0.00017 \mathrm{~T}(\mathrm{~T}-3.7)(41.9-\mathrm{T})^{1 / 2.7}$ \\
$q$ & $q \sim 0.0003 \mathrm{~T}_{\max }\left(\mathrm{T}_{\max }-10.4\right)$ \\
$\mu$ & $\mu \sim 0.09 \exp (0.16 \mathrm{~T})$ \\
\hline
\end{tabular}

$\mathrm{T}=$ average mean temperature of the month in question

The relationship between vector density $v$ and temperature and precipitation was from [20], where $T_{\mathrm{i}}$ is the daily temperature (in this case, the mean monthly temperature), and $T_{\mathrm{i}-37 \mathrm{i}}$ is the mean temperature for the proceeding 37 days (in this case the mean temperature of the preceding month)

$T_{\max }$ is the maximum daily temperature, and $P_{\mathrm{i}-100 \mathrm{j}-16}$ the mean precipitation for the preceding days 100 to 16 . All other parameters are from [19] 
cattle and small ruminant populations were provided to the third administrative level [21]. This data which gives total populations of cattle and small ruminants for each village district is provided in Additional file 1: Dataset S1. Small ruminant populations were not disaggregated into sheep and goat populations, so the total small ruminant population reported was used to estimate the sheep population density in Eq. 1; this resulted in 2466 data points. The geographical area of each $\mathrm{SO}$ was also obtained from [21], and this together with the sheep and cattle populations reported it was possible to estimate the livestock density for each SO (i.e. $h_{\mathrm{c}}$ and $h_{\mathrm{s}}$ in Eq. 1). Climatic data was available for the main settlement at the second administrative level, and this was used for each of the village settlements in that rayon. This climatic data was obtained from [22] and is based on 30-year averages between 1982 and 2012. This climatic data, together with the livestock data, coordinates, and area of each of the third administrative district is also given in the additional data file.

\section{Analysis and mapping}

All data was entered into an Excel spreadsheet; subsequently, analysis and mapping was completed using $R$ statistical software [23]. The basic reproductive number was estimated for each SO from Eq. 1. This was based on the climatic data and livestock populations. $R_{0}$ for each $\mathrm{SO}$ was calculated for each month of the year. The resultant data grid of 2466 data points was smoothed by linear interpolation [24], and isopleth maps were drawn. When $R_{0}$ is below 1 , disease transmission cannot be maintained. When $R_{0}>1$, the proportion of the population immune to the disease (level of herd immunity) to prevent an outbreak of disease is $1-1 / R_{0}$ [25]. Therefore, this also defines the proportion of the population required to be vaccinated to prevent disease outbreaks. For each of the 2466 data points, we estimated the maximum $R_{0}$ from April to October and used this to estimate the proportion of the livestock population required to be vaccinated to prevent outbreaks of BT. These were also plotted on an isopleth map. The maps were drawn in $\mathrm{R}$ using ggplot2 [26]. $\mathrm{R}$ code and associated files are provided in Additional file 2: Dataset S2. We also undertook sensitivity analysis to see how varying the parameters $b, c, \gamma_{\mathrm{c}}$, and $\gamma_{\mathrm{s}}$ affected the number of village communities that had $R_{0}>1$ during July which was the peak month for potential transmission (see Table 2).

\section{Results}

The $R_{0}$ for $\mathrm{BT}$ transmission is displayed for the months April-September. The model indicated that outbreaks were unlikely to occur from October to March. Risk of outbreaks appeared initially mainly in the south Kazakhstan region. This spread across the southern regions, South Kazakhstan, Jambyl, and Almaty, in May. By June, outbreaks were possible in the northern parts of Kazakhstan. $R_{0}$ and hence potential outbreaks peaked in July in the north and north-east regions of Kazakhstan, by which time $R_{0}$ was starting to decrease in the south. In September, $R_{0}$ was decreasing in all regions and in many areas had been reduced below the threshold of transmission. By October, $R_{0}$ was below 1 in all areas of Kazakhstan. Estimated $R_{0}$ transmission for the months of April to September is illustrated in Fig. 2.

The estimated proportion of livestock that need to be vaccinated is illustrated in Fig. 3. There are large parts of the country in the centre and south-east of the country where vaccination is not required, as $R_{0}$ is below 1 throughout the year. In contrast, in the north, vaccination of most animals would be required if the virus was introduced.

Sensitivity analysis indicated that the area in which $R_{0}$ remained above 1 was fairly robust to changes in b, c, $\gamma_{c}$, and $\gamma_{\mathrm{s}}$. At the baseline scenario with the parameters used as defined in Table 1, there were 1422 districts (of 2466) where $R_{0}$ was $>1$ in July. Even halving individual parameters only resulted in the number of districts with $R_{0}>1$ varying by approximately $10-23 \%$ (Table 2 ).

\section{Discussion}

The results obtained clearly indicate there is a heterogeneity of risk, both geographically and temporally, of BT outbreaks in Kazakhstan. This assumes that the BTV can only be transmitted by a vector. There is some evidence for possible transmission by direct contact between animals [27, 28], and it is not known whether this transmission pathway can contribute to outbreaks of disease. Across the whole country, in winter months the risk is negligible. This is because it is too cold for the vector to be active, as mean temperatures across most of Kazakhstan are below freezing from November to March. In April, temperatures are high enough for vector activity in the south, and this spreads north, with peak transmission in northern areas in July. In addition, the activity of vectors is dependent on rainfall [16]. Southern areas

(See figure on next page.)

Fig. 1 Pictorial representation of the parameters that affect $R_{0}$. Parameters affected by temperature and rainfall are indicated 

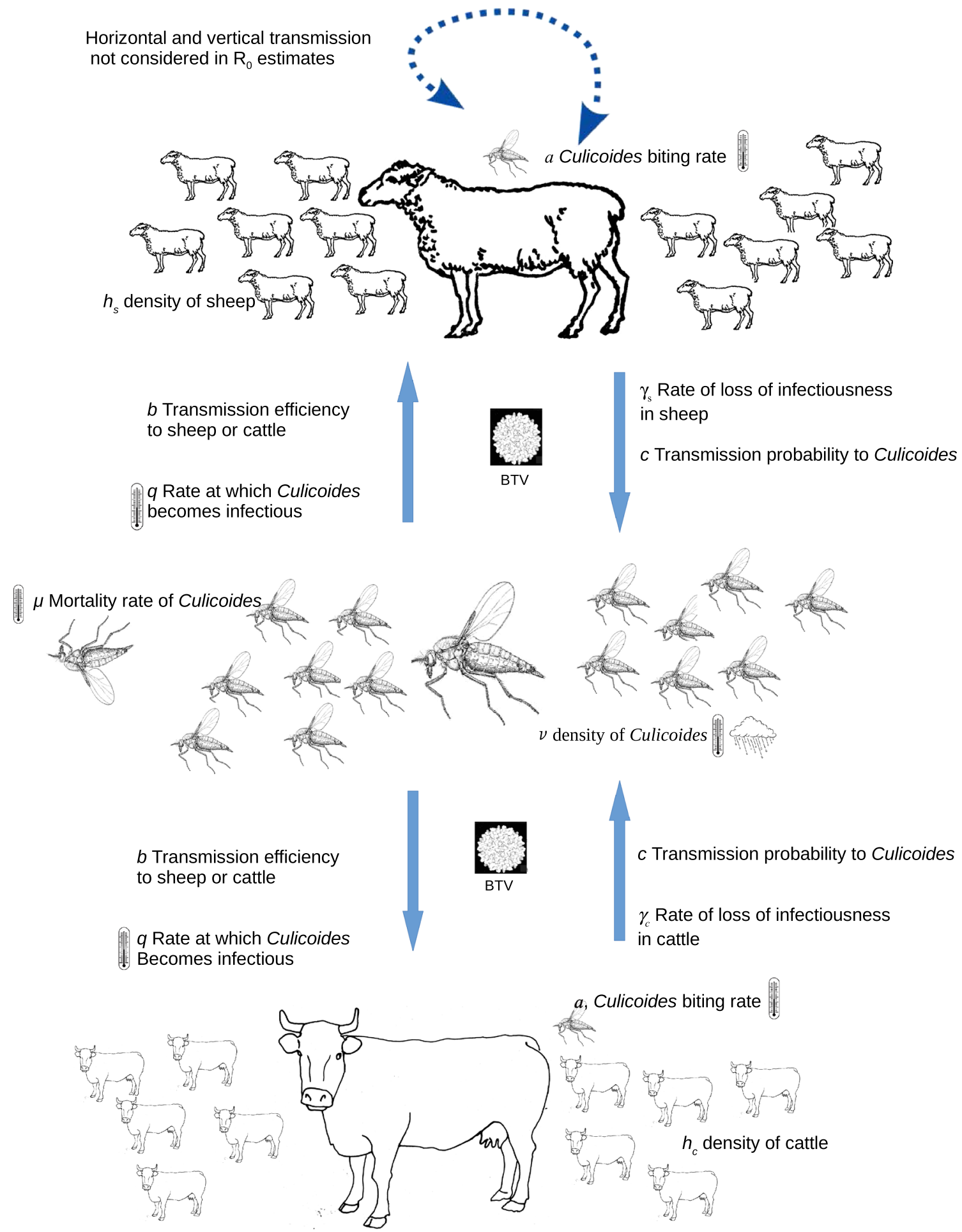

Fig. 1 (See legend on previous page.) 
Table 2 Sensitivity analysis

\begin{tabular}{llllllll}
\hline $\mathrm{b}$ & $N$ & $c$ & $N$ & $g_{c}$ & $N$ & $g_{\mathrm{s}}$ & $N$ \\
\hline $1^{*}$ & $1422^{*}$ & $0.05^{*}$ & $1422^{*}$ & $0.04^{*}$ & $1422^{*}$ & $0.125^{*}$ & $1422^{*}$ \\
0.5 & 1103 & 0.025 & 1103 & 0.02 & 1578 & 0.0625 & 1552 \\
0.3 & 829 & 0.0125 & 735 & 0.012 & 1691 & 0.0375 & 1669 \\
0.2 & 615 & 0.01 & 625 & 0.008 & 1772 & 0.025 & 1757 \\
0.1 & 265 & 0.005 & 265 & 0.004 & 1887 & 0.0125 \\
\hline
\end{tabular}

Number of villages $(N)$ in July with $R_{0}>1$ ) by varying the parameters $b, c, \gamma_{c^{\prime}} Y_{s}$

*Baseline scenario used in the model

One parameter was varied in each scenario, and the other parameters held at baseline
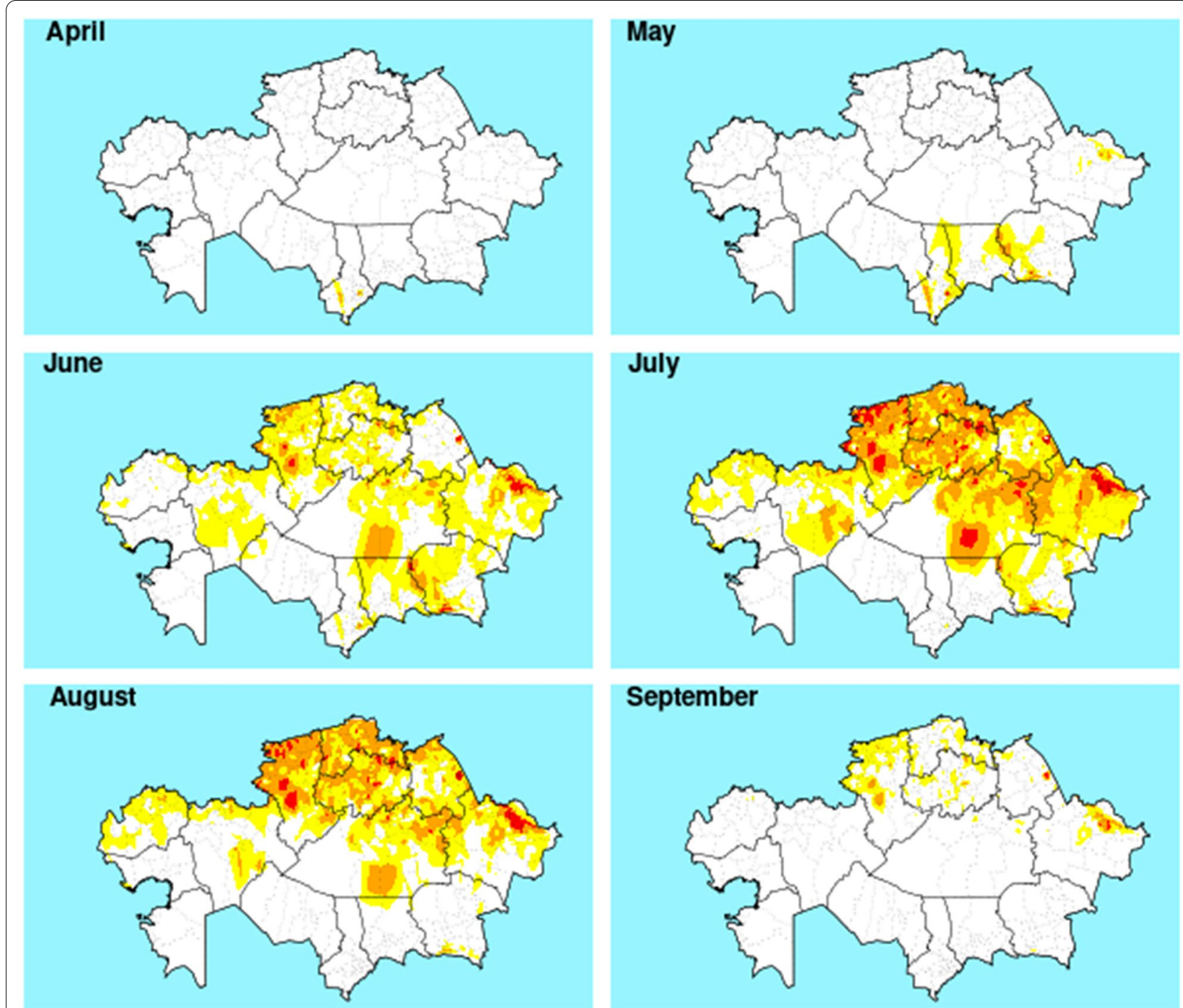

September

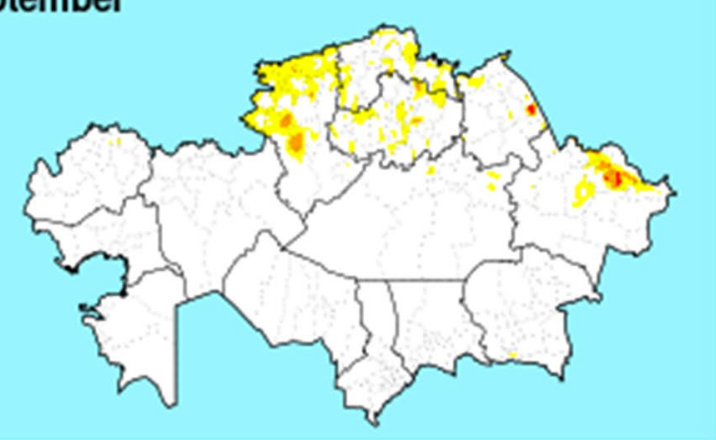

$\mathrm{R}_{0}|<1 \quad 1-2| 2.4|4.8|>8$

Fig. $2 R_{0}$ of transmission of bluetongue in Kazakhstan from April to September 


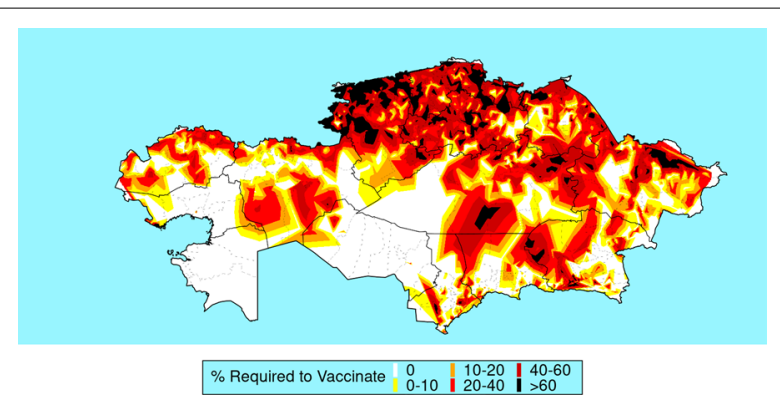

Fig. 3 Estimated proportion of livestock requiring vaccination to prevent outbreaks of bluetongue

such as around Shymkent have relatively low rainfall in the summer months from June to September compared to the wetter spring months of March to May, which will be a factor in the reduced transmission in these areas. In contrast, Petropavl in the north has its highest rainfall in the summer months. Much of central Kazakhstan has very low rainfall year-round, which is associated with the low risk of transmission in these areas, with $R_{0}$ remaining below 1 in many areas. Vaccines are available to prevent BT [29], and our results suggest that to prevent outbreaks of disease, livestock vaccination should be targeted in the northern regions of Kazakhstan. Sensitivity analysis indicated that $R_{0}$ is stable across a range of transmission probabilities and efficiencies and the duration of infectiousness of cattle or sheep, and thus uncertainty in these parameters is unlikely to have a large influence on the conclusions. Other parameters were fixed that is temperature rainfall and livestock density.

This analysis was based on the $R_{0}$ associated with the BTV vector Culicoides. The model for $R_{0}$ was a generic model which was not species-specific [19], but the temperature and rainfall dependency of the vector population was based on work for $C$. obsoletus. A potential weakness of the study is that whilst we used the logistic regression model of [20] to model $v$, the local density of Culicoides, we had to use mean monthly temperatures for the current month and previous month and mean precipitation data as proxies for the actual daily temperature and mean temperatures and precipitation. This was due to availability of the data, and we attempted to project possible risk of outbreaks based on long-term climatic factors rather than the risk described over a small number of seasons. Despite this limitation, specimens of $C$. obsoletus have been reported in various regions of Kazakhstan [11, 12], and hence a model utilizing methods based on $C$. obsoletus would be the most relevant to this study.

There are a number of other Culicoides spp. endemic to the region. A review by Sprygin et al. [30] suggested that
23 species of Culicoides have been detected in Kazakhstan, including widespread species such as $C$. reconditus, C. fascipennis, and C. vexans. C. brevifrontis and C. manchuriensis have been found in Akmola Oblast, in northcentral Kazakhstan [31]. Although there are well over 1000 species of Culicoides, only about 30 are believed to be vector-competent for BTV [32]. The duration of viraemia is less than 2 months in small ruminants and cattle $[33,34]$, and this presents a possible limiting factor for transmission, as the virus should not be able to overwinter in cattle or sheep when there is no Culicoides activity. However, it has been shown that BTV virus can persistently infect ovine $\gamma \delta$ T-cells, and this might provide a mechanism for virus persistence and overwintering [35]. BTV nucleic acid has been detected in field-collected Culicoides spp. larval pools. This supports the hypothesis that the virus can overwinter in vertically infected immature life stages of the vector [36]. In Southern Europe, Turkey, and Iran, C. imicola is an important vector of BTV [37], and in the warmer parts of these regions, the short viraemia in farm animals does not limit the transmission of BTV because of the more favourable climatic conditions. Specimens of C. imicola have not been reported in Kazakhstan, although it has been found in northern Iran [38] just across the Caspian Sea. Modelling has suggested that favourable conditions for C. imicola may be present in the southern most parts of Kazakhstan [39]. Other vectors may be implicated in the spread of BTV northwards in Europe [40]. For example, C. scoticus, in addition to $C$. obsoletus, has been shown to be an efficient vector of BTV [41].

Transmission in Switzerland at altitudes as high as $1500 \mathrm{~m}$ in Lenzerheide in Canton Grisons appears to be possible [41]. There, winter minimums are $-10{ }^{\circ} \mathrm{C}$, summer maximums are $18{ }^{\circ} \mathrm{C}$, and there are only 2 months with a mean temperature above $12.5{ }^{\circ} \mathrm{C}$. In Lenzerheide, the conditions compare unfavourably to most of southern Kazakhstan, and summers are cooler and shorter than in northern Kazakhstan. For example, in Shymkent, in the far south of Kazakhstan, there are 7 months with a mean temperature above $12.5^{\circ} \mathrm{C}$, and winter minimums average $-6{ }^{\circ} \mathrm{C}$, whilst summer highs average $34{ }^{\circ} \mathrm{C}$. In Petropavl, which borders southern Siberia and is $2000 \mathrm{~km}$ farther north, winter lows average $-21^{\circ} \mathrm{C}$ with summer highs averaging $25^{\circ} \mathrm{C}$ with just 3 months where the mean temperature is above $12.5^{\circ} \mathrm{C}$. In addition, there is some evidence that the virus may be able to overwinter in northern Europe [15]. This suggests that if vector-competent species of Culicoides are endemic to Kazakhstan, then there is a risk of outbreaks of BT, and the data displayed in Fig. 2 would represent the risk of outbreaks. However, in regions where there 
is the absence of vector-competent species, then outbreaks of BT should not be possible. Vector-free vertical and horizontal transmission has been reported, but may only be relevant to local on-farm transmission [42]. It is worth noting that serological evidence of BTV has been previously reported in Kazakhstan with a seropositivity of $25 \%$ of 279 cattle and $22 \%$ of small ruminants (sheep and goats) from central and southern Kazakhstan in the period 1996-1998 [9]. Thus, if true, there are likely to be vector-competent species in Kazakhstan and a mechanism other than viraemia in livestock by which the virus can persist through the winter and transmit from one season to the next. C. obsoletus has been reported in some districts of Kazakhstan [11, 12], such as East Kazakhstan. Seropositive cattle which had been imported from Russia were found in this region of Kazakhstan [13], illustrating the risk of outbreaks. However, the extent and distribution of this and other vectorcompetent species is unknown and, therefore, represents an important data gap for understanding the risk of transmission of BTV in Kazakhstan.

\section{Conclusions}

Presently, there have been no recent outbreaks of BT in Kazakhstan. This study shows the high-risk districts for outbreaks of BT should the disease appear and thus helps with epidemic preparedness. In June 2006, BTV appeared in northern Europe for the first time, successfully overwintered, and subsequently caused substantial losses to the farming sector in 2007 and 2008 [43]. This illustrates the need for such preparedness.

\section{Abbreviations}

BT: Bluetongue; BTV: Bluetongue virus; SO: Selski okrugs; $\mathrm{R}_{0}$ : Reproduction number.

\section{Supplementary Information}

The online version contains supplementary material available at https://doi. org/10.1186/s13071-021-04945-6.

Additional file 1: Dataset S1. Data on small ruminant and cattle population for each third level village district, together with the area and coordinates of the district. Climatic data for mean monthly temperature and rainfall is based on the data from the principal settlement in the rayon.

Additional file 2: Dataset S2. R code and associated files.

\section{Acknowledgements}

The work was carried out within the framework of applied scientific research in the field of the agro-industrial complex under the scientific and technical program "Scientific support of veterinary welfare and food safety", under the budget program 267, project BR06249242, Republic of Kazakhstan.

\section{Authors' contributions}

SKA: concept and design of the study. All authors were involved in the study design. AAS: grant holder. KKB, YYM, ASK, AYU, and AYZ: data collection. PRT: data analysis, drafting the manuscript. All authors read and approved the final manuscript.

\section{Funding}

The work was carried out within the framework of applied scientific research in the field of the agro-industrial complex under the scientific and technical program "Scientific support of veterinary welfare and food safety", under the budget program 267, project BR06249242, Republic of Kazakhstan.

\section{Availability of data and materials}

All data used in the analysis can be obtained elsewhere [21, 22]. These data are also provided as Additional file 1: Dataset S1 and Additional file 2: Dataset S2.

\section{Declarations}

Ethics declarations and consent to participate

No human or animal subjects were involved in this study, so ethical approval is not necessary, and there are no ethical issues arising from this manuscript.

\section{Consent for publication \\ Not applicable.}

\section{Competing interests}

The authors declare that they have no competing interests.

\section{Author details}

${ }^{1}$ Saken Seifullin Kazakh Agrotechnical University, Nur-Sultan (Astana), Kazakhstan. ${ }^{2}$ Kazakh Scientific Research Veterinary Institute, Almaty, Kazakhstan. ${ }^{3}$ Section of Epidemiology, Vetsuisse Faculty, University of Zürich, Zürich, Switzerland.

Received: 23 October 2020 Accepted: 11 August 2021

Published online: 25 September 2021

\section{References}

1. Gibbs EP, Greiner EC. The epidemiology of bluetongue. Comp Immnol Microbiol Infect Dis. 1994;17:207-20.

2. Maclachlan NJ. Global implications of the recent emergence of bluetongue virus in Europe. Vet Clin North Am Food Anim Pract. 2010;26:163-71.

3. Mellor PS, Carpenter S, Harrup L, Baylis M, Mertens PPC. Bluetongue in Europe and the Mediterranean Basin: history of occurrence prior to 2006. Prev Vet Med. 2008;87:4-20.

4. Gong QL, Wang Q, Yang XY, Li DL, Zhao B, Ge GY, Zong Y, Li JM, Leng X, Shi K, Liu F. Seroprevalence and risk factors of the bluetongue virus in cattle in China from 1988 to 2019: a comprehensive literature review and meta-analysis. Front Vet Sci. 2021;7:1179.

5. Tabachnick WJ. Culicoides and the global epidemiology of bluetongue virus infection. Vet Ital. 2004;40:144-50.

6. Carpenter S, Wilson A, Barber J, Veronesi E, Mellor P, Venter G, Gubbins S. Temperature dependence of the extrinsic incubation period of orbiviruses in Culicoides biting midges. PLoS ONE. 2011;6:e27987.

7. Clavijo A, Munroe F, Zhou EM, Booth TF, Roblesky K. Incursion of bluetongue virus into the Okanagan Valley, British Columbia. Can Vet J. 2000:41:312-4.

8. Shoorijeh SJ, Ramin AG, Maclachlan NJ, Osburn BI, Tamadon A, Behzadi MA, Mahdavi M, Araskhani A, Samani D, Rezajou N, Amin-Pour A. High seroprevalence of bluetongue virus infection in sheep flocks in West Azerbaijan. Iran Comp Immunol Microbiol Infect Dis. 2010;33:243-7.

9. Lundervold M, Milner-Gulland EJ, O'Callaghan CJ, Hamblin C. First evidence of bluetongue virus in Kazakhstan. Vet Microbiol. 2003;92:281-7.

10. Baigazanov Al, Nurkenova MK, Nurimanov CO. Epizootic monitoring of bluetongue in the territory of East Kazakhstan Oblast. Bull State Univ. 2016;4:12-5.

11. Auezova GA. Hosts and trophic specialization of bloodsucking biting midges (Diptera: Ceratopogonidae, Leptoconopidae) in southeastern Kazakhstan. Russ Entomol J. 2008;17:19-24. 
12. Aubakirova KM. Fauna and ecology of biting midges in the high mountain pastures of the South Western Altai. Bull Altai State Agrar Univ. 2017;10(156):92-5.

13. Singer RS, MacLachlan NJ, Carpenter TE. Maximal predicted duration of viremia in bluetongue virus - infected cattle. J Vet Diag Invest. 2001;13:43-9.

14. Ma J, Gao X, Liu B, Xiao J, Chen H, Wang H. Spatial patterns and risk factors of bluetongue virus infection in Inner Mongolia. China Vector Borne Zoo Dis. 2019;19:525-32

15. Wilson A, Darpel K, Mellor PS. Where does bluetongue virus sleep in the winter? PLoS Biol. 2008;6:e210.

16. Versteirt V, Balenghien T, Tack W, Wint W. A first estimation of Culicoides imicola and Culicoides obsoletus/Culicoides scoticus seasonality and abundance in Europe. EFSA Support Publ. 2017;14:1182E.

17. Anderson RM, May RM. Infectious diseases of humans: dynamics and control. Oxford: Oxford University Press; 1992

18. Ferguson NM, Donnelly CA, Anderson RM. The foot-and-mouth epidemic in Great Britain: pattern of spread and impact of interventions. Science. 2001;292:1155-60.

19. Hartemink NA, Purse BV, Meiswinkel R, Brown HE, de Koeijer A, Elbers ARW, Boender G-J, Rogers DJ, Heesterbeek JAP. Mapping the basic reproduction number $\left(R_{0}\right)$ for vector-borne diseases: a case study on bluetongue virus. Epidemics. 2009;1:153-61.

20. Brugger K, Rubel F. Bluetongue disease risk assessment based on observed and projected Culicoides obsoletus spp. Vector densities. PLoS ONE. 2013;8:e60330.

21. https://stat.gov.kz/official/industry/14/statistic. Accessed: 25 Sept 2019.

22. https://ru.climate-data.org/ Accessed various dates Sept 2019-May 2020.

23. R Core Team. R: A language and environment for statistical computing. R Foundation for Statistical Computing, Vienna, Austria. 2020. https:// www.R-project.org/. Accessed 20 Oct 2020.

24. Akima H, Gebhardt A. akima: Interpolation of irregularly and regularly shaped data. R package version 0.6-2,1. 2020. https://CRAN.R-project. org/package=akima.Accessed 1 July 2021.

25. Fine P, Eames K, Heymann DL. Herd immunity: a rough guide. Clin Inf Dis. 2011;52:911-6.

26. Wickham H. ggplot2: Elegant Graphics for Data Analysis. New York: Springer; 2016.

27. Menzies FD, McCullough SJ, McKeown IM, Forster JL, Jess S, Batten C, Murchie AK, Gloster J, Fallows JG, Pelgrim W, Mellor PS. Evidence for transplacental and contact transmission of bluetongue virus in cattle. Vet Rec. 2008;163:203-9.

28. Batten C, Darpel K, Henstock M, Fay P, Veronesi E, Gubbins S, Graves S, Frost L, Oura C. Evidence for transmission of bluetongue virus serotype 26 through direct contact. PLoS ONE. 2014;9:e96049.

29. Feenstra F, Van Rijn PA. Current and next-generation bluetongue vaccines: requirements, strategies, and prospects for different field situations. Crit Rev Microbiol. 2017;43:142-55.
30. Sprygin AV, Fiodorova OA, Babin YY, Elatkin NP, Mathieu B, England $\mathrm{ME}$, Kononov AV. Culicoides biting midges (Diptera, Ceratopogonidae) in various climatic zones of Russia and adjacent lands. J Vector Ecol. 2014;39:306-15.

31. Akimbekova AF, Akhmetbekov NA, Ibraeva AB. Blood-sucking dipteran insects of Akmola Region. Sci World. 2013;12:74-6.

32. Meiswinkel R, Gomulski LM, Delécolle JC, Goffredo M, Gasperi G. The taxonomy of Culicoides vector complexes-unfinished business. Vet Ital. 2004:40:151-9.

33. Koumbati M, Mangana O, Nomikou K, Mellor PS, Papadopoulos O. Duration of bluetongue viraemia and serological responses in experimentally infected European breeds of sheep and goats. Vet Microbiol. 1999;64:277-85.

34. Bonneau KR, DeMaula CD, Mullens BA, MacLachlan NJ. Duration of viraemia infectious to Culicoides sonorensis in bluetongue virus-infected cattle and sheep. Vet Microbiol. 2002;88:115-25.

35. Takamatsu H, Mellor PS, Mertens PPC, Kirkham PA, Burroughs JN, Parkhouse RME. A possible overwintering mechanism for bluetongue virus in the absence of the insect vector FN1. J Gen Virol. 2003;84:227-35.

36. White DM, Wilson WC, Blair CD, Beaty BJ. Studies on overwintering of bluetongue viruses in insects. J Gen Virol. 2005;86:453-62.

37. Purse BV, Mellor PS, Rogers DJ, Samuel AR, Mertens PP, Baylis M. Climate change and the recent emergence of bluetongue in Europe. Nat Rev Microbiol. 2005;3:171-81.

38. Khezri M, Azimi SM. Seroprevalence of bluetongue disease in sheep in west and northwest provinces of Iran. Vet Res Forum. 2013;4:195-8.

39. Leta S, Fetene E, Mulatu T, Amenu K, Jaleta MB, Beyene TJ, Negussie H, Revie CW. Modeling the global distribution of Culicoides imicola: an ensemble approach. Sci Rep. 2019;9:14187.

40. Wilson A, Mellor P. Bluetongue in Europe: vectors, epidemiology and climate change. Parasitol Res. 2008;103:69-77.

41. Paslaru Al, Mathis A, Torgerson P, Veronesi E. Vector competence of pre-alpine Culicoides (Diptera: Ceratopogonidae) for bluetongue virus serotypes 1, 4 and 8. Parasit Vectors. 2018;11:466.

42. van der Sluijs MTW, de Smit AJ, Moormann RJ. Vector independent transmission of the vector-borne bluetongue virus. Crit Rev Microbiol. 2016:42:7-64

43. Carpenter S, Wilson A, Mellor PS. Culicoides and the emergence of bluetongue virus in northern Europe. Trends Microbiol. 2009;17:172-8.

\section{Publisher's Note}

Springer Nature remains neutral with regard to jurisdictional claims in published maps and institutional affiliations.

Ready to submit your research? Choose BMC and benefit from

- fast, convenient online submission

- thorough peer review by experienced researchers in your field

- rapid publication on acceptance

- support for research data, including large and complex data types

- gold Open Access which fosters wider collaboration and increased citations

- maximum visibility for your research: over 100M website views per year

At BMC, research is always in progress.

Learn more biomedcentral.com/submissions 